\section{Effects of Wildfire on Timber and Forage Production in Arizona}

h. A. PEARSON, J. R. DAVIS, AND G. H. SCHUbERT

Principal Range Scientist, Associate Forest Fuels Specialist, and Principal Silviculturist, respectively, Rocky Mountain Forest and Range Experiment Station,1 Flagstaff, Arizona.

\section{Highlight}

A severe May wildfire decimated an unthinned ponderosa pine stand in northern Arizona, while an adjacent thinned stand was relatively undamaged. Radial growth increased on burned trees where crown kill was less than $60 \%$ and decreased where crown kill was more than 60\%. Burning initially stimulated growth of herbaceous vegetation in both stands. Herbage nutrient value was temporarily enhanced due to burning. Artificially seeded areas produced most herbage 2 years after burning.

Wildfire is a constant threat to ponderosa pine forests in the Southwest, but little has been published about effects of severe wildfire on lesser vegetation. In this case history, both ponderosa

${ }^{1}$ Forest Service, U.S. Department of Agriculture, with central headquarters maintained at Fort Collins in cooperation with Colorado State University; authors stationed at Flag. staff in cooperation with Northern Arizona University. Pearson is now with the Southern Forest Experiment Station, Pineville, Louisiana. pine and herbaceous vegetation were mcasured prior to and following a severe May wildfire in northern Arizona.

\section{Study Area and Methods}

In 1967, lightning started a wildfire in a ponderosa pine (Pinus ponderosa Laws.) stand north of Flagstaff. About 800 acres of pine timber were burned, including two experimental pastures on the Wild Bill Range (Pearson and Jameson, 1967). Since tree and herbage growth had been measured for 5 years prior, the firc provided an opportunity to evaluate the damage and recovery of the vegetation.

The study area burned May 9,1967 , during clear weather, 3 days after a light snow and rain storm (0.14 inch precipitation). The upper layer of litter was relatively dry, the lower litter was moist, and wind averaged 20 to $40 \mathrm{mph}$. The fire danger rating was high.

Before it burned, one pasture (unthinned) had an average of $126 \mathrm{ft}^{2} /$ acre basal area of pine trees which had not been logged or thinned for many years. This unevenaged stand included many young trees established in 1919 through natural regeneration, and some older trees dating back to the 1800 's. The other pasture had been thinned in 1963 to approximately $20 \mathrm{ft}^{2} /$ acre.

The dense, unthinned stand in one pasture burned by crown fire with flames 30 to $40 \mathrm{ft}$ above the tree tops. The thinned stand in the other pasture burned by ground fire with tree scorch several feet high on the boles.

Native understory vegetation before the fire consisted mainly of Arizona fescue (Festuca arizonica Vasey), mountain muhly (Muhlenbergia montana (Nutt.) Hitchc.), bottlebrush 
Table 1. Ponderosa pine measurements on burned and unburned areas for 1966 (prefire) and 1968.

\begin{tabular}{cccccc}
\hline \hline $\begin{array}{c}\text { Area } \\
\text { and } \\
\text { year }\end{array}$ & \multicolumn{2}{c}{ Basal area $\left(\mathrm{ft}^{2} /\right.$ acre $)$} & & \multicolumn{2}{c}{ Canopy cover $(\%)$} \\
\cline { 5 - 6 } & Unthinned & Thinned & & \multicolumn{2}{c}{ Unthinned Thinned } \\
\hline Unburned & & & & & \\
1966 & 108.3 & 20.0 & & 52.2 & 12.8 \\
1968 & 106.7 & 19.2 & & 55.8 & 14.7 \\
Burned & & & & & \\
1966 & 135.4 & 22.4 & & 66.8 & 7.8 \\
1968 & 4.2 & 20.0 & & 2.0 & 9.2 \\
\hline
\end{tabular}

squirreltail (Sitanion hystrix (Nutt.) J. G. Smith), sedge (Carex geophila Mackenz.), and a variety of forbs. The primary shrub was Fendler ceanothus (Ceanothus fendleri A. Gray). Exotic spccics sceded in June aftcr the fire in a portion of the unthinned pasture included orchardgrass (Dactylis glomerata L.) and intermediate wheatgrass (Agropyron intermedium (Host) Beauv.).

Ponderosa pine density was measured by two methods at 45 mechanically spaced locations in each pasture. Tree basal area was measured at breast height by the Bitterlich plotless method (Grosenbaugh, 1952) with a 10-factor prism. Tree crown cover was measured with a spherical densitometer.

Tree growth data were obtained from an increment core extracted at breast height from the south face of 30 trees in the spring of 1969 to evaluate individual growth response. These trees were selected to cover the entire range of crown kill. Growth at breast height provided an estimate of response to thinning and to the burn.

Herbage production (ovendry) by species was determined by clipping and weighing the material under 45 caged plots in each pasture at the end of each growing season. These plots were established in 15 randomly located permanent sampling clusters. Each cluster consisted of three permanent sampling plots at 50 - $\mathrm{ft}$ intervals along a transect line. Of the 45 plots in each pasture, 24 of the thinned and 27 of the unthinned were burned.

Litter was recorded as present or absent at 0.5 -ft intervals along fifteen $100-\mathrm{ft}$ transect lines between the permanent herbage sampling clusters.

Green material from the four principal native forage species was collected seven times on burned and adjacent unburned areas from 1967 through 1969 for analysis of crude protein, phosphorus, and in vitro digestibility. Crude protein and phosphorus were determined by standard methods (AOAC, 1960) and dry-matter digestibility was determined by the two-stage in vitro technique (Pearson, 1969). Each species sample was a composite of material from approximately 10 plants.

\section{Results and Discussion}

\section{Tree Density}

The crown fire essentially eliminated the entire living pine stand on the unthinned area (Table 1). The only surviving trees were on a rocky knoll. On the other hand, there were no significant reductions in tree density (basal area or canopy cover) after the ground fire in the thinned stand, although tree boles were scorched several ft high and needle

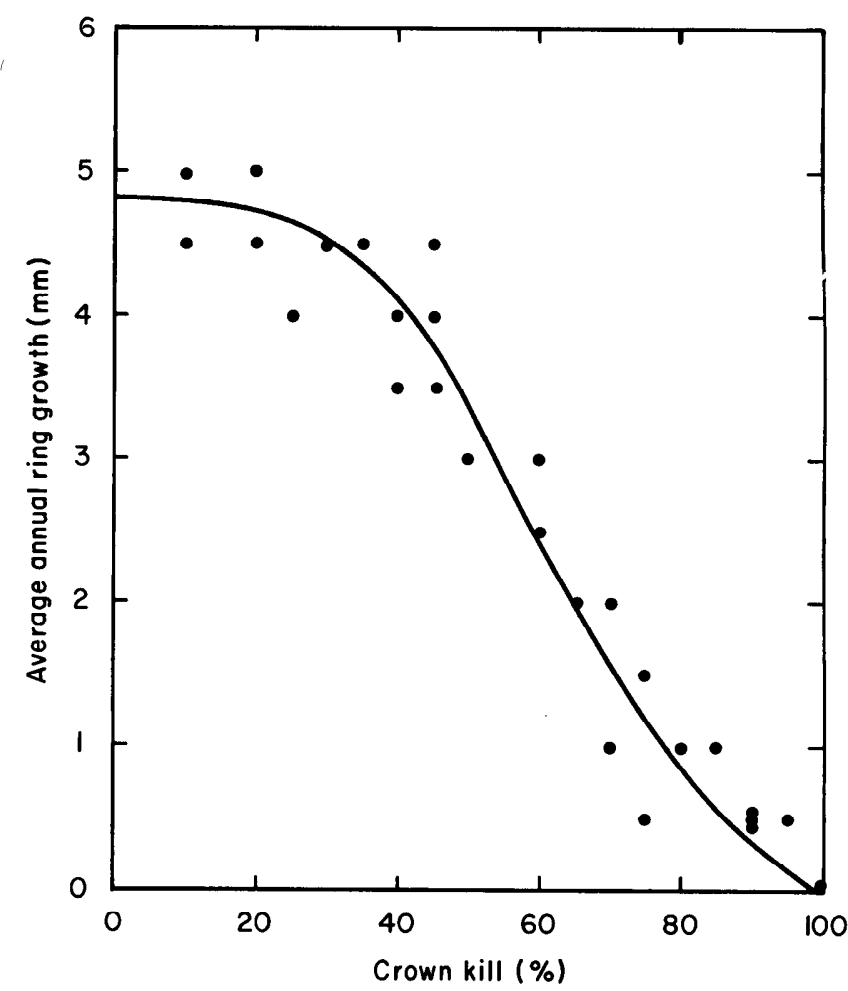

FIG. 1. Relation of diameter growth of ponderosa pine to crown kill by wildfire.

kill averaged $54 \%$. Herman (1954) concluded that neither height of bark scorch nor presence of nearby fuels is related to tree survival. In the Wild Bill Fire, temperatures were high enough in the crowns to kill but not to ignite the needles. Unless needles are killed above the point of maximum crown width, a tree can sustain heavy needle kill without affecting its canopy cover.

\section{Tree Diameter}

Diameter growth of ponderosa pines on the thinned pasture was strongly correlated with percent of crown kill (Fig. 1). Before thinning, the 30 sample trees had an average ring width of 1.2 $\mathrm{mm}$ (Table 2). Trees that lost $50 \%$ or less of their live crown in the fire subsequently averaged 4.3 $\mathrm{mm}$ annual radial growth, with a minimum of 3.0 . Trees that lost 65 to $80 \%$ of their crown grew at an average rate of $1.4 \mathrm{~mm}$-just slightly more than their prethinning rate-while trees with 85 to $95 \%$ kill averaged only $0.6 \mathrm{~mm}$.

Previous pruning studies indicated that up to $40 \%$ of the live crown could be removed without significantly affecting diameter growth if at least $30 \%$ of the total tree height is left in live crown (Heidmann, 1963). In our study, radial growth of all trees with $60 \%$ or less crown kill surpassed the average growth rate after thinning. Trees with $20 \%$ or less crown kill grew at nearly twice their post-thinning rate. 
Table 2. Comparison of radial growth of 30 thinned ponderosa pines before thinning (1957-62), before fire (1963-66), and after fire (1967-68).

\begin{tabular}{|c|c|c|c|c|}
\hline \multirow{2}{*}{$\begin{array}{l}\text { Percent of } \\
\text { crown kill }\end{array}$} & \multirow{2}{*}{$\begin{array}{c}\text { DBH } \\
1969 \\
\text { (Inches) }\end{array}$} & \multicolumn{3}{|c|}{$\begin{array}{l}\text { Average annual radial growth } \\
(\mathrm{mm}) \text { by periods }\end{array}$} \\
\hline & & $1957-62$ & $1963-66$ & $1967-68$ \\
\hline 0 & 13.9 & 1.34 & 3.25 & 5.00 \\
\hline 0 & 14.4 & 1.34 & 2.50 & 4.50 \\
\hline 10 & 8.4 & 1.34 & 2.50 & 4.50 \\
\hline 10 & 12.4 & 1.17 & 2.50 & 5.00 \\
\hline 20 & 12.7 & 1.34 & 3.00 & 4.50 \\
\hline 20 & 13.1 & 1.34 & 2.25 & 5.00 \\
\hline 25 & 14.2 & 1.34 & 2.75 & 4.00 \\
\hline 30 & 14.2 & 1.17 & 2.25 & 4.50 \\
\hline 35 & 10.4 & 1.17 & 2.25 & 4.50 \\
\hline 40 & 11.7 & 1.17 & 2.75 & 4.00 \\
\hline 40 & 13.8 & 1.00 & 2.25 & 3.50 \\
\hline 45 & 11.5 & 1.17 & 2.50 & 4.00 \\
\hline 45 & 12.1 & 1.17 & 2.00 & 4.50 \\
\hline 45 & 19.9 & 1.34 & 2.50 & 3.50 \\
\hline 50 & 13.4 & 1.17 & 2.00 & 3.00 \\
\hline 60 & 9.9 & 1.17 & 2.50 & 3.00 \\
\hline 60 & 10.0 & 1.17 & 2.50 & 2.50 \\
\hline 65 & 9.3 & 1.17 & 2.50 & 2.00 \\
\hline 70 & 16.9 & 1.17 & 2.00 & 1.00 \\
\hline 70 & 17.3 & 1.17 & 2.00 & 2.00 \\
\hline 75 & 12.7 & 1.17 & 3.00 & 1.00 \\
\hline 75 & 13.3 & 1.17 & 2.75 & 1.50 \\
\hline 80 & 12.5 & 1.17 & 2.75 & 1.00 \\
\hline 85 & 8.6 & 1.17 & 2.50 & 1.00 \\
\hline 90 & 5.1 & .84 & 2.25 & .50 \\
\hline 90 & 6.3 & 1.00 & 2.50 & .50 \\
\hline 90 & 10.3 & 1.17 & 2.25 & .50 \\
\hline 95 & 12.7 & 1.17 & 2.00 & .50 \\
\hline 100 & 8.2 & 1.17 & 1.75 & .00 \\
\hline 100 & 10.7 & 1.34 & 2.50 & .00 \\
\hline Ave. 54 & 12.0 & 1.19 & 2.43 & 2.70 \\
\hline
\end{tabular}

Trees respond to release, reduced competition, and to increased nutrients. Ponderosa pines, however, do not always respond immediately to release (Schubert, 1971). Therefore, growth measured after the fire included one or two annual rings when the treés wcre still growing at or near their before-thinning rate. The reduction of competition and the possible improvement in the soil nutrient level may also account for part of the higher growth rate following the burn.

\section{Litter}

Litter coverage on both burned areas was about the same immediately after the burn, although the unthinned stand had more originally (Table 3).
Table 3. Number of hits per 100 observation points of litter before and after wildfire.

\begin{tabular}{lllll}
\hline \multicolumn{1}{c}{ Type of burn } & 1965 & 1966 & 1967 & 1968 \\
\hline $\begin{array}{l}\text { No fire (unburned } \\
\text { portion of both stands) }\end{array}$ & 77.1 & 85.4 & 77.7 & 80.1 \\
Ground fire (thinned stand) & 67.0 & 77.1 & 45.3 & 51.3 \\
Crown fire (unthinned stand) & 82.0 & 82.0 & 46.6 & 42.3 \\
\hline
\end{tabular}

Litter coverage increased slightly 1 year after the fire on the thinned stand because the fire did not consume the overstory foliage. The unthinned stand in which the fire crowned, did not have the needle foliage necessary to increase coverage of ground litter.

\section{Total Herbage}

Total herbage production increased slightly on both unthinned and thinned pastures the first growing season after the fire (Table 4). Total production continued to increase the second growing season on the unthinned area but decreased on the thinned area.

Grass
Production of grass and grasslike plants was higher the first year after fire where exotic grasses were seeded than on unseeded areas. The second year, production of grass and grasslike plants increased 12 times more than the previous year on seeded areas, but only about six times more on the unseeded areas.

Duvall and Linnartz (1967) found fire did not greatly influence grass production in southern pine forests. They attributed a short-period increase in production on an ungrazed paddock to reduction of needle litter; apparently heavy accumulations of litter smothered the grass production. In the present study the removal of litter by fire from the thinned pasture apparently provided opportunity for more grass production.

\section{Forbs}

Forb production was greater on the thinned than on the unthinned pasture during the first growing season after the fire, but it did not hold this superiority (Table 4). During the second growing season, forb production on the unthinned was more than triple the amount on the thinned pasture.

\section{Shrubs}

Shrub and half-shrub seedlings were more numerous and current twig and leaf production was higher after burning. Shrubs such as Fendler ceanothus increased on both unthinned and thinned burned pastures. Ceanothus seeds, which lie dormant in the litter for years, germinate rapidly 
Table 4. Herbage production (lb/acre) on burned and unburned areas for 1966 (prefire), 1967, and 1968.

\begin{tabular}{lrrrr}
\hline \hline $\begin{array}{c}\text { Pasture } \\
\text { condition }\end{array}$ & $\begin{array}{c}\text { Grass and } \\
\text { grasslike }\end{array}$ & Forbs & $\begin{array}{c}\text { Shrubs and } \\
\text { half-shrubs }\end{array}$ & Total \\
\hline Unthinned pasture & & & & \\
Unburned & & & & \\
1966 & 40 & 46 & 1 & 87 \\
1967 & 66 & 26 & 7 & 99 \\
1968 & 59 & 13 & 0 & 72 \\
Burned (native) & & & & \\
1966 & 31 & 1 & 3 & 35 \\
1967 & 24 & 36 & 3 & 63 \\
1968 & 148 & 452 & 13 & 613 \\
Burned (seeded) & & & & \\
1966 & 14 & 1 & 0 & 15 \\
1967 & 38 & 13 & 2 & 53 \\
1968 & 469 & 498 & 56 & 1023 \\
& & & & \\
Thinned pastures & & & & \\
Unburned & & & & \\
1966 & 558 & 75 & 19 & 654 \\
1967 & 443 & 73 & 1 & 517 \\
1968 & 452 & 28 & 10 & 490 \\
Burned (native) & & & & \\
1966 & 603 & 47 & 0 & 650 \\
1967 & 594 & 139 & 36 & 769 \\
1968 & 470 & 145 & 23 & 638 \\
\hline
\end{tabular}

following a burn (Curtis, 1952; Quick, 1959). Lay (1956) found, in southern pine forests, browse forage was reduced for 2 years aftcr burning while herbaceous vegetation was increased for 3 years although no change was noted in total understory production.

\section{Forage Quality}

Crude protein, phosphorus, and in vitro digestibility were higher in the forages from the burned area the first growing season (Table 5). Increases in digestibility and phosphorus lasted through the second growing season, while increases in protein lasted only the initial growing season following the wildfire. Lay (1957) indicated a similar improvement in protein and phosphorus following prcscribed burning of southern pine forests.

\section{Summary}

Ponderosa pine canopy reduction resulted in more forage for livestock or wildlife. Fire enhanced germination of Fendler ceanothus, a good wildlife species, and forb and grass production increased. Seeding the burn with orchardgrass and intermediate wheatgrass improved grass production signifi-
Table 5. Nutrient content $(\%)$ of the native forages on burned and unburned areas.

\begin{tabular}{|c|c|c|c|c|c|c|}
\hline \multirow[b]{2}{*}{ Date } & \multicolumn{2}{|c|}{$\begin{array}{l}\text { In vitro } \\
\text { digestibility }\end{array}$} & \multicolumn{2}{|c|}{ Crude protein } & \multicolumn{2}{|c|}{ Phosphorus } \\
\hline & Burned & $\begin{array}{c}\text { Un- } \\
\text { burned }\end{array}$ & Burned & $\begin{array}{c}\text { Un- } \\
\text { burned }\end{array}$ & Burned & $\begin{array}{c}\text { Un- } \\
\text { burned }\end{array}$ \\
\hline June 1967 & 63.4 & 62.5 & 16.3 & 12.0 & 0.43 & 0.23 \\
\hline August 1967 & 65.6 & 57.2 & 18.6 & 12.1 & .39 & .32 \\
\hline October 1967 & 68.7 & 59.9 & 9.6 & 7.9 & .27 & .23 \\
\hline July 1968 & 65.2 & 62.0 & 9.2 & 10.0 & .25 & .22 \\
\hline August 1968 & 61.1 & 53.6 & 9.5 & 9.8 & .22 & .21 \\
\hline $\begin{array}{l}\text { September } \\
1968\end{array}$ & 51.3 & 50.1 & 9.6 & 9.6 & .27 & .22 \\
\hline July 1969 & 56.5 & 56.3 & - & - & - & - \\
\hline
\end{tabular}

cantly. Forage quality was improved temporarily after the burning. The wildfire destroyed nearly all trees in an unthinned pasture, but caused little reduction in tree density in a heavily thinned pasture. Pines with $60 \%$ or less crown kill grew faster while those with over $60 \%$ crown kill grew slower than their preburn rate.

\section{Literature Cited}

AOAC. 1960. Official methods of analysis. Ass. Offic. Agr. Chem. Ed. 9, Washington, D.C. 832 p.

Curtis, James D. 1952. Effect of pregcrmination treatments on the viability of ceanothus seed. Ecology 33: $577-578$.

Duvall, Vinson L., and Norwin E. Linnartz. 1967. Influences of grazing and fire on vegetation and soil of longleaf pine-bluestem range. J. Range Manage. 20:241-247.

Grosenbaugh, L. R. 1952. Plotless timber estimates-new, fast, easy. J. Forest. 50:32-37.

HeidManN, L. J. 1963. Heavy pruning reduces growth of southwestern ponderosa pine. U.S. Forest Serv. Res. Note RM-3. 3 p. Rocky Mt. Forest and Range Exp. Sta., Fort Collins, Colo.

Herman, F. R. 1954. A guide for marking fire-damaged ponderosa pine in the Southwest. U.S. Dep. Agr., Forest Serv., Rocky Mt. Forest and Range Exp. Sta. Res. Note 13. 4 p. Fort Collins, Colo.

Lay, Daniel W. 1956. Effects of prescribed burning on forage and mast production in southern pine forests. J. Forest. 54:582-584.

LaY, Daniel W. 1957. Browse quality and the effects of prescribed burning in southern pine forests. J. Forest. 55:342-347.

Pearson, Henky A. 1969. Digestibility trials: in vitro techniques. U.S. Dep. Agr. Misc. Pub. 1147, p. 85-92.

Pearson, Henry A., and Donald A. Jameson. 1967. Relationship between timber and cattle production on ponderosa pine range-the Wild Bill Range. 10 p. U.S. Forest Serv., Rocky Mt. Forest and Range Exp. Sta., Fort Collins, Colo.

Quick, Clarence R. 1959. Ceanothus seeds and seedlings on burns. Madrono 15:79-81.

Schubert, Gilberert H. 1971. Growth response of evenaged ponderosa pines related to stand density levels in Arizona. J. Forest. 69:857-860. 